\title{
Teaching Japanese Language in Tertiary and Secondary Education: StATE AND PRivate Institutions in Romania
}

\author{
Angela DRAGAN \\ "Dimitrie Cantemir" University \\ Faculty of Foreign Languages and Literatures \\ Bucharest, Romania \\ draganangela@yahoo.com
}

\begin{abstract}
In Romania, Japanese language, literature and culture are taught at university level in two private universities and two state universities. Japanese departments are part of either a Faculty of Letters or a Faculty of Languages and Literatures. Students have to choose another language to study, in addition to Japanese. This gives them a dual major / dual specialization. A large number of graduates decide on pursuing a teaching career in one of their specializations. My paper looks at the way in which university provides an educational background for teachers at lower and upper education. It also looks into the way it shapes secondary education through its curriculum. This refers to compulsory education in an integrated national system of education. But, in the last ten years, this perspective has broadened. Language schools, which are not part of this integrated system, have appeared. Some of them teach exclusively Japanese language and Japanese culture classes. In the beginning, the students were mainly adults, age 18+ but in the last several years, more children have started to be interested in attending classes in these language schools. My paper also discusses this new perspective. A questionnaire and its results will also be presented on this topic. It will show not only the increasing number of young learners but also, their very young age, which goes as far as primary school. This tendency, in studying Japanese as a foreign language, could provide a preview into its development at the secondary level.
\end{abstract}

Keywords: tertiary education; secondary education; language schools; younger learners

\section{Povzetek}

V Romuniji se na terciarni ravni japonski jezik, literatura in kultura poučujejo na dveh privatnih in dveh državnih univerzah. Oddelki za japonologijo so bodisi del Fakultete za humanistiko bodisi del Fakultete za jezike in literaturo. Poleg japonščine se morajo študenti odločiti še za en tuji jezik. To posledično pomeni, da je njihov študij sestavljen iz dveh smeri oziroma specializacij. Številni diplomanti se odločajo za učiteljski poklic na enem od izbranih področij. Pričujoči prispevek predstavi, kako univerza zagotavlja določeno raven pedagoške izobrazbe za učitelje na nižji in višji sekundarni stopnji. Prispevek prav tako osvetli, kako univerzitetni študijski programi krojijo ustroj sekundarnega izobraževanja, kar se nanaša na obvezno izobraževanje $v$ integriranem nacionalnem sistemu izobraževanja. A v zadnjem desetletju se situacija spreminja. Pojavile so se jezikovne šole,

Acta Linguistica Asiatica, 8(1), 2018.

ISSN: 2232-3317, http://revije.ff.uni-lj.si/ala/

DOI: 10.4312/ala.8.1.91-99 
ki niso del integriranega sistema. Nekatere od njih poučujejo izključno japonski jezik in kulturo. Sprva so bili udeleženci teh šol predvsem odrasli, starejši od 18 let. Članek posveti nekaj pozornosti tudi novostim na tem področju. Opaziti je namreč mogoče, da v zadnjih nekaj letih narašča zanimanje za tovrstne jezikovne šole tudi med otroki. Prispevek predstavi vprašalnik in rezultate ankete $v$ zvezi s tem. Izsledki raziskave kažejo, da ne narašča le število mladih, ki se zanimajo za japonski jezik in kulturo, temveč se je tudi starostna meja učencev znižala, ki sega celo pred primarno, osnovnošolsko raven. Te tendence nam lahko nudijo vpogled $v$ bodoči razvoj japonščine kot tujega jezika na sekundarni ravni.

Ključne besede: terciarno izobraževanje; sekundarno izobraževanje; jezikovne šole; mlajši učenci

\section{Introduction}

In Romania, Japanese language, literature and culture are taught at the university level in two state universities and two private universities: University of Bucharest, from 1975 and Babes-Bolyai University, from 2008, in Cluj-Napoca and "Dimitrie Cantemir " Christian University, from 1999 and "Hyperion" University, from 1995, both in Bucharest.

Japanese departments from these universities are part of the Faculty of Languages and Literatures in the case of University of Bucharest and "Dimitrie Cantemir" Christian University. Babes-Bolyai University has included Japanese as part of the Department of Asian Languages and Literatures from the Faculty of Letters. In " Hyperion" University, Japanese is part of the Department of Letters and Foreign Languages of the Faculty of Social and Humanistic Sciences.

Students who study at these faculties have to choose one more language in addition to Japanese. There are various combinations but the most attractive one is Japanese and English. Such double-major course opens numerous opportunities and rises the students' chances to find work. Japanese can be studied as a major at the University of Bucharest and Babes-Bolyai University, and as a minor at the "Dimitrie Cantemir" Christian University and "Hyperion" University.

According to the Bologna treaty on higher education, undergraduate studies take 3 years. Romania started implementing the system during the 2005-2006 academic year. The full course is thus divided into 6 semesters, with 14 weeks per each semester. Undergraduate studies can be followed by a 2-year master' s program. Three of the universities have masters programs that include Japanese studies. At the University of Bucharest, there is an East-Asian Studies Masters, at "Dimitrie Cantemir" Christian University, a Translation and Communication under Intercultural Context Masters and at "Hyperion" University an Intercultural Communication and Professional Translation Masters. 


\section{Teacher training system}

In Romania, students who graduate from the Faculty of Foreign Languages and Literatures and the Faculty of Letters usually decide to pursue a teaching career as one of their majors though their number has dropped due to economic reasons. Besides teaching, those who choose to study languages consider jobs such as that of an interpreter or translator, or publishing house jobs.

In order to become a teacher in a primary or secondary school, as well at university level, students have to take a number of courses that are integrated in 2 modules. The first one gives the graduate student the right to teach in kindergartens, primary, secondary schools and high-schools. The second module allows teaching in highschools, post high-school education and university.

At each university, these courses are managed by the teacher Training Department, a special department that is constantly under the supervision of the Faculty of Educational Science from each university. The curricula includes: pedagogy, teaching and evaluation methodology, didactics, class management and a certain number of hours of teaching in schools. In the case of English, French or German, it is easy to assign schools where students can do their training but in the case of Japanese, this has proven to be more difficult. Each school where training takes place is supposed to have a mentor who guides and observes the students. The ministry has not yet approved a mentor for Japanese for primary school level to high-school level. Therefore, for example at "Dimitrie Cantemir" Christian University we, the teachers of Japanese, supervise the training process.

\section{Courses and textbooks}

Regarding the subjects taught in the Japanese departments, there are three main areas: Japanese literature and culture, Japanese linguistics and Japanese language.

Next, I will discuss the case of the Japanese department in "Dimitrie Cantemir" Christian University. The course in Japanese literature and culture is taught for 6 semesters. The first semester is focused on Japanese culture as first year students need to get familiar with Japan' s civilization and especially historical periods. The next five semesters follow the history of Japanese literature in chronological order. The goal of this subject is for students to get a comprehensive image of Japanese literature and important writers. It also helps build a solid Japanese culture background.

Japanese linguistics is taught for 6 semesters following the linguistic structure of the language.

Japanese language as a language course is also taught for 6 semesters. It focuses on teaching grammar and on practicing Japanese. During the 6 semesters, we focus on 
teaching grammatical structures, oral and written communication, listening and translations. A certain number of classes are spent on teaching Japanese writing, cf. kanji. The textbook that we have been using for the last 7 years is Genki. An Integrated Course in Elementary Japanese, volumes 1 and 2. It takes around 3 semesters to finish both volumes. After Genki. An Integrated Course in Elementary Japanese, we use several different textbooks depending on the level of each group, for example: Chūkyū he ikō 中級へ行こう by Hirai, Etsuko \& Miwa, Sachiko, published by Suriē nettowāku in 2004, Nyū apurōchi. Chūkyū nihongo ニュウアプローチ中級日本語 by Noboru Oyanagi published by Gobun kenkyūsha or Nihongo nama chūkei 日本語生中継 by Sugimoto Fusako and published by Kuroshio. With students reaching their third year of studies, we have also used raw teaching materials such as news articles from News Web Easy (NHK News Web, n.d.) or presentations in Japanese of their own graduation paper. Our goal is to cover not only grammatical structures and kanji characters but also to put them in practice through listening, reading or writing. This intends to help students become independent learners who can work effectively in broadening their studies.

Japanese studies in "Hyperion" University are also assigned 6 semesters to teach Japanese linguistics and Japanese history of literature. In the first year of studies, one or two semesters are dedicated to Japanese culture and civilization. In the second year of studies, a practical course of Japanese is taught for 2 semesters.

The Faculty of Letters from Babes-Bolyai University offers 5 semesters of Japanese language that start with intrasentence patterns, then intersentence patterns and followed by an integrated course. Another subject offered for 5 semesters is called Intensive reading, writing and lexicon that starts at a beginner level and goes as high as a preintemediate level. A course on Japanese literature is also included for 6 semesters. As it can be observed from their curriculum several optional courses are available, as well (Babeş-Bolyai University Cluj-Napoca, Faculty of Letters, 2016).

At the University of Bucharest, Japanese language structure and Japanese language practice are 2 subjects that are taught for 6 semesters. Japanese civilization is offered for 2 semesters, throughtout the first year of studies. It is followed by a Japanese literature and culture course which is taught for 4 semesters.

Studying Japanese at higher education level provides the students with a comprehensive view of Japanese language, literature and culture. The acquired knowledge complements academic level and helps them in their future careers. Some of the students follow careers linked to Japan, and some of them pursue further academic careers, such as master or PhD programmes. 


\section{Japanese language teaching institutions}

In the next part of my paper, I will focus on institutions that teach Japanese at the secondary level. The Association of Japanese Language Teachers ルーマニア日本語 教師会 has noticed that in the last 5 or 6 years the number of young learners of Japanese language has increased. An overview of this situation was needed as several new schools or centers appeared.

My survey includes state and private institutions as well. Such division seems to be the most visible difference among them at this moment. Both state and private institutions address primary school and secondary school pupils, described usually as young learners. Nevertheless, as it can be seen in the discussion following that private institutions are by far larger in number. Private initiative has been quicker in suppling a demand regarding Japanese language and culture felt in Romanian society. On the other hand, however, it is more difficult for state schools to introduce new subjects since the curriculum need to have Ministry approval.

\subsection{Questionnaire and results}

I designed a 12 question questionnaire, as it follows, for examining the current situation:

1) The name of the institution/school/center

2) The year Japanese courses for children started

3) Age range

4) Number of teachers non-native/native

5) Number of classes/week

6) Number of children/year

7) Level according to Japanese Language Proficiency Test

8) Textbooks, educational materials used in these institutions

9) Library, database

10) Events to promote Japanese language and culture

11) Workshops held in these institutions/schools/centers

12) Reasons for choosing to study Japanese

The questionnaire was sent to 13 institutions, out of which 9 of them answered it. Among them, 8 are located in Bucharest and the other 5 are in other cities. The first 2 institutions are state-owned while others are private ones. Here is the list of the institutions:

1) “Ion Creanga" High-School (Bucharest)

2) "Emil Racovita" Elementary School (Bucharest)

3) BSmart Center (Bucharest)

4) Romanian-Japanese Studies Center (Bucharest) 
5) "Akino" Japanese Center (Bucharest)

6) Nihongo Mirai Center (Bucharest)

7) International House (Bucharest)

8) "Sakura" Japanese School (Bucharest)

9) Active Volunteering Association (Baia-Mare)

10) Himawari Romanian-Japanese Association (Iasi)

11) "Sakuranbo" Association (Constanta)

12) Musashino Center (Brasov)

13) Simone Educational Center (Craiova)

"Ion Creanga" High-School represents a different case in studying Japanese ${ }^{1}$ because it is taught as a compulsory subject, having the same status as other languages, such as English, French or German. As such, it can be one of the compulsory subjects in the Romanian Baccalaureate. Even though "Emil Racovita" Elementary School is a state owned institution, like "Ion Creanga" High-School, it only has an optional course, cf. 1 hour per week. The course started to be offered in the year 2000 and is held upon request from parents and pupils. There is a non-native teacher who is in charge of the course, within which ikebana, calligraphy and karaoke workshops are conducted during the "Scoala Altfel" week². The pupils who can take this class are aged 9 to 14 and corsspond to $3^{\text {rd }}$ to $8^{\text {th }}$ graders.

Most of the private centers have started developing after the year 2000. They are what is generaly considered a language school, but only 3 of them: BSmart, International House and Simone Educational Center teach other languages besides Japanese, for example English. There is one other exception; the Romanian-Japanese Studies Center offers other courses, as well, but only on Asian languages such as Korean and Chinese.

Romanian-Japanese Studies Center has been active since 2005 and it offers classes for students and children. It has built connections with the Romanian-American University and Japanese there can be studied as an optional language, among other European languages, by students attending the university. The age of the children enrolled in Romanian-Japanese Studies Center starts at 14 , and their number is around 50. There are 2 classes per week, 2 altogether. They are taught by one native and one non-native teacher. The level of Japanese according to the Japanese Language Proficiency Test ranges from N5 to N1. Several workshops such as taiko, kendo, ikebana or origami are organized. For the promotion of Japanese culture, each year the center organizes Japanese Culture Days at the Romanian-American University.

\footnotetext{
${ }^{1}$ This case is presented in detail by Lungu (2018, pp. 101-112).

2 "Scoala Altfel" week represents a week of alternative learning, outside the school. It is held every year, during spring.
} 
"Sakuranbo" Association from Constanta was established in 2010 and it offers Japanese classes for children as young as 9 years old. It has 2 non-native teachers. It organizes the Aki Matsuri festival every year. It also holds workshops in schools and other institutions in order to promote Japanese culture and language. Origami, shodo and ikebana are also taught in the Japanese classes. The levels of Japanese according to the Japanese Language Proficiency Test are N5 to N4.

In 2012, the Active Volunteering Association began in Baia-Mare. Their courses are held at the local library by a non-native teacher once a week for 90 minutes. Origami, shodo and haiku workshops are part of the association' s activities to promote Japanese culture. The levels of Japanese according to the Japanese Language Proficiency Test are N5 to N4.

In the same year, International House in Bucharest that specializes in English classes, started a course on teaching Japanese to children. The children' $s$ age is 8 and above. A 2-hour course is taught once a week. There are 2 non-native teachers and the level of Japanese is beginner up to N5, Japanese Language Proficiency Test. At the end of each school year and on Christmas, it holds a matsuri to promote Japanese culture and language.

The "Akino" Japanese Center first started its activities in 2014. It has one native and 1 non-native teacher. The youngest learners are 7 years old. The level of Japanese taught is from beginner to N2 level, according to Japanese Language Proficiency Test. Origami, kamishibai and Japanese games are all part the center' s workshops and promotion of Japanese culture.

One of the most recent centers that have Japanese courses is BSmart. It is a center for foreign languages and Japanese is one of them. They have a non-native teacher and the courses include Japanese for children as young as 7 years old. The level of Japanese is level N5 to level N4.

\subsection{Teachers and textbooks}

Most of the teachers that are employed in these institutions are Romanian, in other words, non-native speakers. 90\% of them graduated from a Faculty of Foreign Languages or a Faculty of Letter. Therefore, their educational background is that of the foreign language learning and teaching.

One of the questions concerned are the textbooks used. Genki. An Integrated Course in Elementary Japanese and Minna no Nihongo series are among the textbooks that are mostly used in these institutions. Two of the institutions mention using Marugoto, as well. Some centers use textbooks to prepare the students for the Japanese Language Proficiency Test. One of the schools mentions that pupils do not have a specific textbook but a kit that is put together by the teacher in order to suit 
their needs. Textbooks like Genki. An Integrated Course in Elementary Japanese and Minna no Nihongo have not been designed for young learners. Therefore, it is rather difficult to use them for this age category.

As mentioned before, many of these schools have workshops on origami, shodo, ikebana, or even organize matsuri as their students are very interested in Japanese culture. This represents one of the ways to attract new students.

Anime, manga and cosplay have been a source of inspiration for most of the students who want to study Japanese language. These represent one of the main reasons for choosing to study Japanese. They are also the reason why the number of very young learners has increased in recent years.

This takes us to discussing the goal of these institutions. Most of their students/pupils do not seek to follow a career that involves Japan and Japanese culture. They want to get acquainted with Japanese culture in general, and Japanese proves to be more like a hobby to them. Consequently, the focus of teaching is on cultural aspects rather than on the language itself.

\section{Conclusion}

From the point of view of their goals, both universities and secondary level schools and language centers have different objectives they try to meet. On one hand, Japanese departments at a high education level give special attention to Japanese language and its indeepth understanding, acquisition and fluency. On the other hand, private schools and language centers need to provide a larger context to meet the needs of their students. Nevertheless, in Romania, the rising number of students at both levels, secondary and tertiary, show a trend in studying Japanese. The relatively young age of these new Japanese learners has raised the awareness of a new generation of learners who have a different background and education as the previous ones. As teachers of Japanese, one should address the issue of new textbooks or materials that are more age appropriate and that could attract more students eager to study Japanese, in the future. Moreover, a close collaboration between universities and schools, language centers could provide a wider working framework and shape the future learning of Japanese.

This conference has, also, given us the chance to take a survey on Japanese language teaching in Romania at all levels, which has not been done in the last 10 years and to evaluate the current situation. The survey has to continue in order to include all institutions in Romania, and to give a general view on Japanese language and culture education. 


\section{References}

Babeş-Bolyai University Cluj-Napoca, Faculty of Letters. (2016). Retrieved from http://lett.ubbcluj.ro/academic-programmes-2/ba/?lang=en

Lungu, M. (2018). Overview of Japanese Language in Upper Secondary Education and School Curriculum in Romania. Acta Linguistica Asiatica, 8(1), 101-110. doi:10.4312/ala.8.1.101110

NHK News Web. (n.d.) Retrieved from http://www3.nhk.or.jp/news/easy/

Program de studiu Limba şi literatura română - o limbă şi literatura modernă (2014-2017). Universitatea din Bucureşti Facultatea de litere. Retrieved from http://www.unibuc.ro/facultati/litere/:e/facultati/litere/docs/2014/oct/16 1920 28Pla n de invatamant 2014-2017 LLR-LLS.pdf

Universitatea Crestina DIMITRIE CANTEMIR (n. d.). Retrieved from http://limbi-straine.ucdc.ro/en/ 